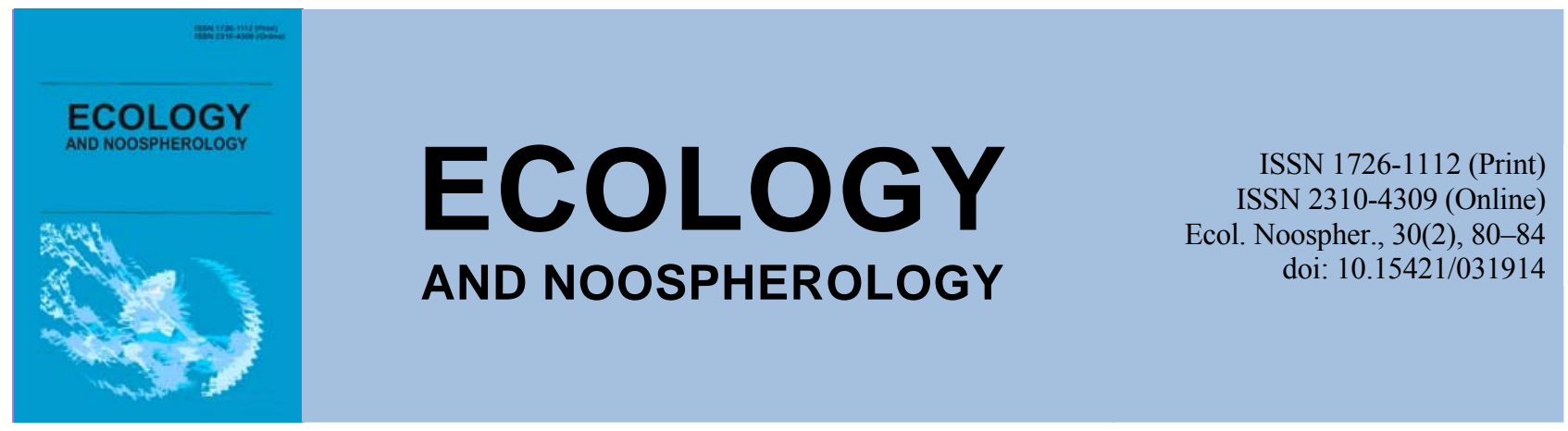

\title{
The formation of herbage cover in forty-year-old plantation of black locust on the reclaimed dump in the Western Donbass
}

\author{
O. M. Masiuk, E. S. Spekhova
}

Oles Honchar Dnipro National University, Dnipro, Ukraine

Article info

Received 14.11.2019

Received in revised form

21.11.2019

Accepted 29.11.2019

Oles Honchar Dnipro

National University

Gagarin Ave., 72, Dnipro,

49010, Ukraine.

Tel.: +38-095-401-14-65

E-mail: almas63636@gmail.com
Masiuk, O. M., Spekhova, E. S. (2019). The formation of herbage cover in forty-year-old plantation of black locust on the reclaimed dump in the Western Donbass. Ecology and Noospherology, 30(2), 80-84. doi:10.15421/031914

The purpose of this paper is to study the formation of herbage cover in forty-year-old plantation of black locust (Robinia pseudoacacia L.), which has been growing under various forest growth conditions of artificial edaphotopes, which differed in stratigraphy and dumping depth on the reclaimed dump in the Western Donbass. The dump consisted of «empty» carefully planned mine rock; on its surface one-, two- and three-tiered structures of reclaimed land have been artificially formed. The maximum number of species in grass canopy of the black locust plantations has been recorded on technosol with typical chernozem. The formation of the grass canopy in plantations growing on technosol, consisted only of mine rock, the number of species depended on the power of edaphotope: with a decrease in dumping, a decrease in plant species has been observed. All studied variants are dominated by perennials. Under more favorable soil conditions, (variants 1 and 2) plants without vegetative movement dominate. With a decrease in the depth of dumping, the percentage of plants with slight vegetative movement increases. The representatives of plants with vegetative movement can be found under all forest growth conditions created on reclaimed lands. A specific trait of lithosol (variants 2,3,4) is an increase in mesoxerophytes, xerophytes and oligamegatrophs with a decrease in the power of dumping. Heliophytes predominate on studied variants with chernozem and loam with a dumping of one meter. Species partially demanding light have a significant advantage with the decrease in the power of dumping on lithosol variants with depth less than 0.6-0.3 meters. Among the coenomorphs, the dominance of ruderal and steppe complexes have been revealed. In the first case it is explained by the influence of anthropogenic factors (fire), followed by the first stage of the restoration, namely colonization by weed plants; in the second case, it is caused by the influence of surrounding phytocenosis of undisturbed land and presence of herbal plants seeds from fertile soil level in pedosoil, which set the direction of succession towards the formation of zonal communities. Meadow and psammophytic coenotypes involved in the formation of flora indicate different types of forest growth conditions created by artificial soils.

Keywords: herbage cover; Robinia pseudoacacia L.; bioecomorphic analysis; reclamation of disturbed lands

\section{Формування трав'яного покриву в насадженнях робінії звичайної на рекультивованих землях Західного Донбасу}

\author{
О. М. Масюк, Є. С. Спєхова
}

\section{Дніпровський національний університет імені Олеся Гончара, Дніпро, Украӥна}

Проаналізовано результати досліджень трав'янистої флори, яка формувалася в сорокарічних насадженнях робінії звичайної в різних лісорослинних умовах, штучно створених на рекультивованому фітотоксичному відвалі Західного Донбасу на конструкціях, які відрізнялися стратиграфією і потужністю відсипки. Було встановлено, що максимальна кількість видів травостою була зафіксована на техноземах, в яких застосовувався чорнозем звичайний. Формування травостою в насадженнях на літоземах, чисельність видів залежала від потужності едафотопу: зі зменшенням відсипки спостерігалось зменшення видів рослин. На всіх варіантах дослідження домінують багаторічники. У більш сприятливих грунтових умовах панують вегетативно нерухливі рослини. При зменшенні потужності відсипки збільшується відсоток 
вегетативно малорухливих рослин. Характерною особливістю літоземів є збільшення показників мезоксерофітів, ксерофітів та олігамегатрофів при зменшенні потужності відсипки. Серед ценоморфів було виявлено домінування рудерального та степового комплексів. Лучні та псамофітні ценотипи, які брали участь у формуванні флори, вказують на різні типи лісорослинних умов, створених штучними грунтами.

Ключові слова: травостій; Robinia pseudoacacia L.; біоекоморфічний аналіз; рекультивація порушених земель

\section{Вступ}

Вугілля є основним джерелом енергії, який покращує економічний та соціальний розвиток у багатьох країнах світу. Однак видобуток передбачає витіснення великої кількості зайвого матеріалу (шахтних відходів) від видобутку вугілля. Це антропогенна зміна структури грунту, який має глибокий вплив на стійкий розвиток екосистем на великих площах, особливо в регіонах 3 порушеним середовищем (Lei et al., 2016).

Експлуатація мінеральних ресурсів призвела до руйнування значної території $\mathrm{i}$ викликала серйозні екологічні проблеми. Екологічне відновлення i рекультивація шахт та відвалів стали важливими компонентами стратегій сталого розвитку багатьох країн (Lei et al., 2016).

Таким чином, на сьогодні глобальний інтерес представляє спостереження та відновлення порушених технікою земель, на яких створюються техногенні ландшафти 3 низькою біологічною продуктивністю i специфічними геофізичними i геохімічними властивостями. Утворюючи своєрідні «провали» $\mathrm{i}$ «бар'єри», вони спотворюють «нормальний» хід фундаментальних процесів, що відбуваються в біосфері. Крім того, вони є основними джерелами забруднення повітря, перебуваючи поблизу населених пунктів погіршують санітарно-гігієнічні умови життя населення (Lei et al., 2016; Pandey et al., 2016; Masiuk, 2017, 2018; Gautam et al., 2018; Maiti, Ahirwal, 2019).

Мета даної роботи $\epsilon$ вивчення формування трав'яного покриву в сорокарічних насадженнях робінії звичайної (Robinia pseudoacacia L.), яка зростала в різних лісорослинних умовах штучно створених едафотопів, які відрізнялися стратиграфією і потужністю відсипки на рекультивованому відвалі Західного Донбасу.

\section{Об’скти та методи досліджень}

Польові дослідження були зосереджені на експериментально-виробничій ділянці лісової рекультивації № 2 Дніпровського національного університету імені Олеся Гончара (Дніпропетровська обл., Павлоградський р-н), яка була сформована на відвалі шахти «Благодатна». Відвал складався знизу «порожньою» ретельно спланованою шахтною породою, на поверхні якої були штучно сформовані одно-, дво- i триярусні структури рекультивованих земель. Загальна площа $-11,4$ га.

Шахтні породи (вуглисті сланці), потужність відсипки яких 10-14 м, фітотоксичні, оскільки містять у своєму складі пірит. У результаті його окислення утворюється сірчана кислота, яка, підкисляючи грунтовий розчин, шкідливо впливає на ріст і розвиток рослин. Цей хімічний процес супроводжується виділенням тепла, обумовлюючи сухість порід і збіднюючи їх органічною речовиною. Тому при рекультивації їх перекривають шарами різних гірських порід і насипанням грунтів для ізоляції від атмосферного впливу і тим самим запобігання вивітрюванню піриту.

Стаціонарні спостереження проводилися в сорокарічних насадженнях Robinia pseudoacacia L. на постійних пробних дільницях на чотирьох варіантах рекультивованих земель (стратиграфія зверху вниз):

варіант 1 - 0-35 см - грунтова маса чорнозему звичайного, 35-85 см - давньоалювіальний суглинок,
85-140 см - технічна суміш, що складається 3 червонобурого суглинку i давньоалювіального піску (розташований на плато та у верхній третині схилу відвалу);

варіант 2 - 100 см - середній суглинок, глибше шахтна порода (розташований у середній третині схилу відвалу);

варіант 3 - $30 \mathrm{~cm}$ - середній суглинок, $30 \mathrm{~cm}$ - супісок, глибше - шахтна порода (розташований у середній третині схилу відвалу);

варіант 4 - 30 см - легкий суглинок, глибше - шахтна порода (розташований у середній частині схилу відвалу).

Різноякісні едафічні ресурси представлені педоземами (варіант 1) та літоземами (варіанти 2, 3, 4) (за класифікацією Yeterevskaya et al., 2008).

$\mathrm{y}$ процесі досліджень використано такі геоботанічні методи досліджень: стаціонарний, описовий, метод пробних площ, проведено біоекоморфічний аналіз (Belgard, 1950, 1971; Programma i metodika .., 1974; Tarasov, 2005; Yaroshenko, 1961). Видовий склад визначався за «Визначником вищих рослин України» (Opredelitel vysshikh rasteniy Ukrainy, 1987).

\section{Результати та їх обговорення}

У зв'язку 3 різними лісорослинними умовами, які впливають на розвиток деревостану, представляло інтерес розглянути формування травостою в насадженнях робінії звичайної. Екоморфічний аналіз травостою в насадженнях робінії звичайної приведено в табл. 1 .

На першому варіанті, особливістю якого є наявність чорнозему звичайного у верхній частині едафотопу, сорокарічні насадження робінії звичайної досягли середньої висоти 10,5 м та діаметра $10,9 \mathrm{~cm}$. На одному гектарі зареєстровано 1250 дерев. Тип екологічної структури - напівосвітлений, друга вікова стадія розвитку (жердняк). Зімкнутість крони - 0,9.

На педоземах, у насадженнях робінії звичайної травостій представлений 17 видами рослин, серед яких домінують багаторічні рослини (60\%), зустрічаються дворічні (25\%), однорічні (10\%) та напівкущі (5 \%). За темпами вегетативного розмноження переважають вегетативно нерухливі рослини (50\%), вегетативно малорухливі (30 \%) та вегетативно рухливі (20\%). За клімаморфами домінують гемікриптофіти (90 \%); в наявності терогемікриптофіти $-8 \%$, геофіти $-1 \%$ та хамефіти - $1 \%$. За трофоморфами переважають мезотрофи $(50 \%)$ та мегатрофи (30\%), зустрічаються олігомегатрофи (10\%), оліго-мезотрофи (5\%) та рослини засолених грунтів (5\%). За гігроморфами найбільше мезоксерофітів (45\%) та ксерофітів (30\%), присутні ксеромезофіти (20\%) та мезофіти (5\%). Залежно від відношення до сонячного світла домінують геліофіти (70\%), решта видів частково вимогливі до світла (30 \%). Екологічний аналіз показує, що в травостої зустрічаються рудеранти (40 \%), степанти (35\%), пратанти (10\%), сильванти (10\%) та псамофіти (5\%).

На другому варіанті, який представлений максимальною відсипкою гірських порід, середня висота дерев становить 9,55 м, діаметр - 10,6 см. На одному гектарі зареєстровано 1850 дерев. Тип екологічної структури - напівосвітлений, друга вікова стадія розвитку. Зімкнутість крон - 1 .

Травостій представлений 11 видами, серед яких домінують багаторічники (80 \%), незначна кількість дворічників $(10 \%)$, однорічників (5\%) та напівкущів (5\%). 


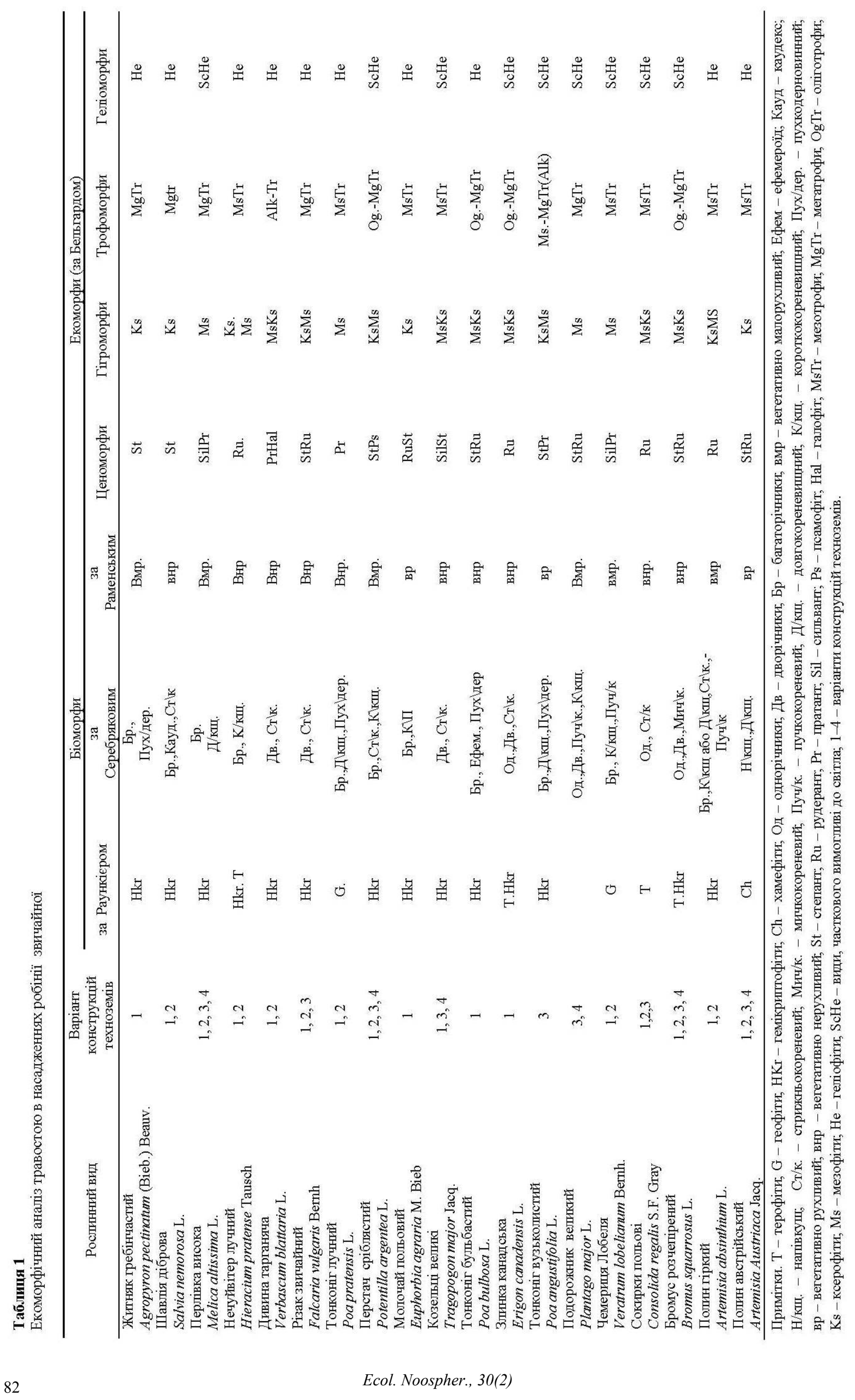


За темпами вегетативного розмноження зустрічаються вегетативно нерухливі (60 \%), вегетативно малорухливі (30 \%) та вегетативно рухливі (10 \%). За клімаморфами переважають гемікриптофіти (50 \%) та терогемікриптофіти (30\%), крім того, присутні хамефіти (10\%), геофіти (10\%). За адаптацією рослин до живлення розподіл видів відбувався так: мезотрофи (50 \%), мегатрофи (20\%), олігомегатрофи (20\%) та рослини засолених грунтів (10\%). По відношенню до вологи грунту переважають ксеромезофіти (45 \%), 3 якими конкурують мезоксерофіти (25\%), мезофіти (25\%) та ксерофіти (5\%). Залежно від відношення до сонячного світла домінують геліофіти (80 \%), незначна кількість видів частково вимогливих до світла $(20 \%)$. За класифікацією ценоморфів зустрічаються рудеранти (30\%), степанти (30\%), пратанти (20\%), сильванти (10\%) та псамофіти $(10 \%)$.

Насадження робінії звичайної на третьому варіанті 3 відсипкою 0,6 м досягли середньої висоти $-8,5$ м та діаметра - 8,7 см. На одному гектарі зареєстровано 726 дерев. Тип екологічної структури - освітлений, збігається з третьою віковою стадією розвитку (зрідження). Зімкнутість крон $-0,5$.

Травостій представлений 9 видами. Серед них зустрічаються багаторічники (35\%), дворічники (35\%), однорічники (25\%) та напівкущі (5\%). За темпами вегетативного розмноження переважають вегетативно малорухливі види (50\%), у два рази менше вегетативно нерухливих (25 \%) та вегетативно рухливих (25\%). Клімаморфи представлені гемікриптофітами (90\%), хамефітами (5\%) та терогемікриптофітами (5\%). У класифікації за вимогливістю до родючості грунту зустрічаються олігамегатрофи (40\%), мегатрофи (30\%), мезотрофи (30\%), які є показником наявності в грунті поживних речовин. Гігроморфи представлені ксеромезофітами (35\%), мезоксерофітами (35 \%), мезофітами $(20 \%)$ та ксерофітами (10\%). На території значне домінування видів, частково вибагливих до світла (90). За адаптацією до біогеоценозу переважають степанти (45\%) та рудеранти (30\%), зустрічаються сильванти (10\%), пратанти (10\%) та псамофіти (5\%).

На четвертому варіанті 3 мінімальною відсипкою гірських порід середня висота дерев - 6, 9 м та діаметр 6,1 см. На одному гектарі зареєстровано 30 дерев (сухостійні). Тип екологічної структури освітлений, третя вікова стадія розвитку - зрідження.

Травостій представлений 7 видами, серед яких багаторічників - $55 \%$, дворічників - $40 \%$, однорічників $3 \%$ та напівкущів - $2 \%$. За темпами вегетативного розмноження переважають вегетативно малорухливі види (50\%), конкуренцію їм складають вегетативно нерухливі (30\%) та вегетативно рухливі види $(20 \%)$. Ситуація 3 клімаморфами незмінна, домінуючими є гемікриптофіти (90 \%). За адаптацією рослин до живлення майже рівномірне співвідношення мегатрофів (35\%), олігомегатрофів (35\%) та мезотрофів (30\%). По відношенню до водного режиму переважають мезоксерофіти (40 \%) та мезофіти (40 \%), зустрічаються ксеромезофіти (10\%) та ксерофіти (10\%). За адаптацією рослин до світлового режиму панують види, частково вибагливі до світла (90\%), зафіксована незначна кількість геліофітів (10\%). Екологічний аналіз показав, що в рослинному покриві переважають степанти (48 \%), рудеранти (40\%), сильванти (8 \%), пратанти (2\%) та псамофіти (2\%).

\section{Висновки}

у насадженнях робінії звичайної максимальна кількість видів травостою була зафіксована на техноземах, в яких застосовувався чорнозем звичайний. При формуванні травостою в насадженнях на техноземах, конструкції яких складалися тільки 3 гірських порід, чисельність видів залежала від потужності едафотопу: зі зменшенням відсипки спостерігалось зменшення видів рослин.

На всіх варіантах дослідження домінують багаторічники. У більш сприятливих грунтових умовах (варіанти 1 и 2 ) панують вегетативно нерухливі рослини. При зменшенні потужності відсипки збільшується відсоток вегетативно малорухливих рослин. В усіх лісорослинних умовах, створених на рекультивованих землях, зустрічаються представники вегетативно рухливих рослин. Характерною особливістю літоземів (варіанти 2, 3, 4) є збільшення показників мезоксерофітів, ксерофітів та олігамегатрофів при зменшенні потужності відсипки.

На «чорноземному» та суглинковому варіанті з відсипкою в один метр переважають геліофіти. При зменшенні потужності відсипки на літоземних варіантах до 0,6 і 0,3 м значну перевагу мають види, частково вимогливі до світла.

Серед ценоморфів було виявлено домінування рудерального та степового комплексів, що пояснюється в першому випадку впливом антропогенних факторів (пожежі), після чого відбувалася перша стадія відновлення - заселення бур'янами; у другому випадку - впливом оточуючих фітоценозів непорушених земель та успадкуванням педоземами насінного матеріалу трав'яних рослин з родючим шаром грунту, які задають напрям сукцесії на шляху формування зонального співтовариства. Лучні та псамофітні ценотипи, які брали участь у формуванні флори, указують на різні типи лісорослинних умов, створених штучними грунтами.

\section{References}

Belgard, A. L. (1950). Lesnaya rastitelnost yugo-vostoka USSR [Forest vegetation of southeast of the Ukrainian SSR]. Kiev (in Russian).

Belgard, A. L. (1971). Stepnoye lesovedeniye [Steppe forestry]. Lesnaya promyshlennost, Moscow (in Russian).

Gautam, M., Pandey, B., \& Agrawal, M. (2018). Identification of indicator species at abandoned red mud dumps in comparison to residential and forest sites, accredited to soil properties. Ecological Indicators, 88, 88-102.

Lei, H., Peng, Z., Yigang, H., Yang, Z. (2016). Vegetation and soil restoration in refuse dumps from open pit coal mines. Ecological Engineering, 94, 638-646.

Maiti, S. K., Ahirwal, J. (2019). Ecological Restoration of Coal Mine Degraded Lands. Phytomanagement of Polluted Sites, $83-111$.

Masiuk, O. M. (2017). Dynamika formuvannya travostoyu v nasadzhennyakh oblipykhy krushynopodibnoyi na riznoyakisnykh variantakh rekultyvatsiyi porushenykh zemel Zakhidnoho Donbasu [Dynamics of formation of gras stand in plantation of common sea buckthorn on reclamations of disturbed lands of different qualities in the Western Donbass]. Issues of steppe forestry and forest reclamation of soils, 46, 64-76 (in Ukrainian).

Masiuk, O. M. (2018). Dynamika formuvannya travostoyu v topolevykh nasadzhennyakh na riznoyakisnykh variantakh rekultyvatsiyi porushenykh zemel Zakhidnoho Donbasu [Dynamics of grass stand formation in poplar plantations on different types of reclamations of disturbed lands of Western Donbass]. Ecology and Noospherology, 29(2), 97-103 (in Ukrainian).

Opredelitel vysshikh rasteniy Ukrainy (1987) [The determinant of higher plants of Ukraine]. Ed. Yu. N. Prokudin. Kiev (in Russian)

Pandey, V. C., Bajpai, O., Singh, N. (2016). Plant regeneration potential in fly ash ecosystem. Urban Forestry \& Urban Greening, 15, 40-44.

Programma i metodika biogeotsenoticheskikh issledovaniy (1974) [Program and methods of biogeocenotic studies]. Ed. N. V. Dulis. Moscow (in Russian). 
Tarasov, V. V. (2005). Flora of Dnipropetrovsk and Zaporizhzhia regions [Flora Dnipropetrovskoyi ta Zaporizkoyi oblastey]. Lira, Dnipropetrovsk (in Ukrainian).

Travleyev, A. P., Ovchinnikov, V. A., Zverkovsky, V. N., (1988). Biogeotsenoticheskiy pokrov Zapadnogo Donbassa, yego tekhnogennaya dinamika i optimizatsia [The biogeocenotic cover of Western Donbass, its man-made dynamics and optimization]. Dnepropetrovsk (in Russsian).
Yaroshenko, P. D. (1961). Geobotanika. Osnovnyye ponyatiya, napravlenia i metody [Geobotany. Basic concepts, directions and methods]. Moscow, Leningrad (in Russian).

Yeterevskaya, L. V., Momot, G. F., Lechtier, L. V. (2008). Rekultyvovani hrunty: pidkhody do klasyfikatsiyi i systematyky [Recultivated soils: approaches to classification and systematics]. Gruntoznavstvo, 9(3-4), 147-150 (in Ukrainian). 